BNL-112586-2016-JA

\title{
Metal-Metal Chalcogenide Molecular Precursors to Binary, Ternary, and Quaternary Metal Chalcogenide Thin Films for Electronic Devices
}

\author{
Ruihong Zhang, Seonghyuk Cho, Daw Gen Lim, \\ Xianyi Hu, Eric A. Stach, Carol A. Handwerker, and Rakesh Agrawal
}

Submitted to Nanoscale

March 2016

Center for Functional Nanomaterials

Brookhaven National Laboratory

\author{
U.S. Department of Energy \\ USDOE Office of Science (SC), \\ Basic Energy Sciences (BES) (SC-22)
}

\footnotetext{
Notice: This manuscript has been authored by employees of Brookhaven Science Associates, LLC under Contract No. DE-SC0012704 with the U.S. Department of Energy. The publisher by accepting the manuscript for publication acknowledges that the United States Government retains a non-exclusive, paid-up, irrevocable, world-wide license to publish or reproduce the published form of this manuscript, or allow others to do so, for United States Government purposes.
} 


\section{DISCLAIMER}

This report was prepared as an account of work sponsored by an agency of the United States Government. Neither the United States Government nor any agency thereof, nor any of their employees, nor any of their contractors, subcontractors, or their employees, makes any warranty, express or implied, or assumes any legal liability or responsibility for the accuracy, completeness, or any third party's use or the results of such use of any information, apparatus, product, or process disclosed, or represents that its use would not infringe privately owned rights. Reference herein to any specific commercial product, process, or service by trade name, trademark, manufacturer, or otherwise, does not necessarily constitute or imply its endorsement, recommendation, or favoring by the United States Government or any agency thereof or its contractors or subcontractors. The views and opinions of authors expressed herein do not necessarily state or reflect those of the United States Government or any agency thereof. 
BNL-112586-2016-JA

\section{Metal-Metal Chalcogenide Molecular Precursors to Binary, Ternary, and Quaternary Metal Chalcogenide Thin Films for Electronic Devices}

Received 00th January 20xx, Accepted 00th January 20xx

DOI: $10.1039 / \times 0 \times x 00000 x$

\author{
Ruihong Zhang ${ }^{a}$, Seonghyuk Cho ${ }^{b}$, Daw Gen Lim ${ }^{a}$, Xianyi Hu ${ }^{a}$, Eric A. Stach ${ }^{c}$, Carol A. Handwerker ${ }^{a}$, \\ and Rakesh Agrawal ${ }^{\mathrm{b}}$
}

www.rsc.org/

Bulk metals and metal chalcogenides are found to dissolve in primary amine-dithiol solvent mixtures at ambient conditions. Thin-films of CuS, SnS, $\mathrm{ZnS}, \mathrm{Cu}_{2} \mathrm{Sn}\left(\mathrm{S}_{x}, \mathrm{Se}_{1-\mathrm{x}}\right)_{3}$, and $\mathrm{Cu}_{2} \mathrm{ZnSn}\left(\mathrm{S}_{x} \mathrm{Se}_{1-\mathrm{x}}\right)_{4}$ $(0 \leq x \leq 1)$ were deposited using the as-dissolved solutions. $\mathrm{Cu}_{2} \mathrm{ZnSn}\left(\mathrm{S}_{\mathrm{x}} \mathrm{Se}_{1-\mathrm{x}}\right)_{4}$ solar cells with efficiencies of $6.84 \%$ and $7.02 \%$ under AM 1.5 illumination were fabricated from two example solution precursors, respectively.

Metal chalcogenides, such as $\mathrm{Cu}_{2} \mathrm{~S}, \mathrm{Cu}_{2} \mathrm{Se}, \mathrm{CuS}$, CuSe, SnS, SnSe, ZnS, ZnSe, $\mathrm{Cu}_{2} \mathrm{Sn}\left(\mathrm{S}_{x} \mathrm{Se}_{1-x}\right)_{3} \quad(0 \leq x \leq 1) \quad$ (CTSSe) and $\mathrm{Cu}_{2} \mathrm{ZnSn}\left(\mathrm{S}_{x} \mathrm{Se}_{1-\mathrm{x}}\right)_{4} \quad(0 \leq x \leq 1)(\mathrm{CZTSSe})$ have received substantial attention for their applications as photovoltaics, ${ }^{1-10}$ optoelectronics, ${ }^{11,12}$ piezoelectronics, ${ }^{13,14}$ and thermoelectronics. ${ }^{15-17}$ Direct solution processing of these semiconductor thin films by roll-to-roll printing on flexible substrates has a great potential to produce low-cost and wearable electronic devices. However, the extremely low solubility of metals and chalcogenide in common solvents, coupled with impurity contamination (e.g. $\mathrm{O}$ and $\mathrm{Cl}$ ) derived from elemental sources, have previously slowed down the development of direct solution methods.

To date, the most successful direct solution approach for depositing metal chalogenide thin films is based on hydrazine solutions. Mitzi et al. dissolved $\mathrm{SnS}_{2}$ and $\mathrm{In}_{2} \mathrm{Se}_{3}$ powders in anhydrous hydrazine, and deposited $\mathrm{SnSe}_{2-x} \mathrm{~S}_{\mathrm{x}}$ and $\mathrm{In}_{2} \mathrm{Se}_{3}$ as active channels in thin-film transistors. ${ }^{18,19}$ Similar methods were successfully applied to CIGSSe ${ }^{20-22}$ and CZTSSe thin-film solar cells. $^{23,24}$ Unfortunately, using hydrazine creates additional safety and health risks during device processing due to its high toxicity, instability, and carcinogenic properties. In addition, given that zinc and zinc chalcogenides (e.g. ZnS and

\footnotetext{
${ }^{a}$ School of Materials Engineering, Purdue University, West Lafayette, IN 47907, USA, E-mail: ruihong.zhang.1@purdue.edu; handwerker@purdue.edu.

${ }^{b}$ School of Chemical Engineering, Purdue University, West Lafayette, IN 47907 ,

USA, Corresponding author: Rakesh Agrawal, E-mail: agrawalr@purdue.edu.

c. Center for Functional Nanomaterials, Brookhaven National Laboratory, Upton, NY 11973, USA, E-mail: estachbnl@gmail.com.

+ Electronic Supplementary Information (ESI) available: including photos of solutions, the electrolytic conductivity measurements on solvents and zinc solutions, TGA results, CZTS film deposition and characterization, CZTSSe film composition analysis, and J-V curves of solar cells. See DOI: 10.1039/x0xx00000x
}

ZnSe) are barely dissolved in hydrazine, a slurry was used for the deposition of CZTSSe thin films. ${ }^{23}$ It is therefore of interest to develop a less toxic and more stable solvent system that is highly capable to dissolve a diverse range of materials.

Toward this goal, Webber et al. reported that nine $\mathrm{V}_{2} \mathrm{Vl}_{3}$ chalcogenides and tellurium were soluble in a mixture of 1,2ethylenediamine and 1,2-ethanedithiol. ${ }^{25-27}$ Then, Lin et al. showed that $\mathrm{Cu}_{2} X$ and $\operatorname{In}_{2} \mathrm{X}_{3}(\mathrm{X}=\mathrm{S}, \mathrm{Se})$ are also soluble in the same solvent mixture, and semiconductor alloys, CulnS $\mathrm{Se}_{1-x}$ $(x=0 \sim 1)$, were prepared by annealing combined metalchalcogenide solutions. ${ }^{28}$ However, these studies do not report any device performance based on this ethylenediamineethanedithiol solvent mixture. The question that remains to be answered is whether an amine-thiol solvent system is suitable for fabricating thin-film electronic devices.

Here, we demonstrate that a versatile primary aminedithiol solvent system can readily dissolve not only metal chalcogenides (e.g. $\mathrm{Cu}_{2} \mathrm{~S}, \mathrm{Cu}_{2} \mathrm{Se}, \mathrm{CuS}$, CuSe, SnS, SnSe, $\mathrm{In}_{2} \mathrm{~S}_{3}$, $\mathrm{In}_{2} \mathrm{Se}_{3}, \mathrm{Ag}_{2} \mathrm{~S}$, and $\mathrm{Ag}_{2} \mathrm{Se}$ ) but also pure metals (e.g. $\mathrm{Cu}, \mathrm{Zn}, \mathrm{Sn}$, and $\mathrm{In}$ ) at high concentrations (e.g. $\geq 0.3 \mathrm{M})$ at room temperature and ambient pressure. The fact that bulk zinc can quickly dissolve in this primary amine-dithiol solvent mixture at high concentrations $(>0.75 \mathrm{M})$ is critical to the deposition of CZTSSe thin films. Given that zinc and zinc chalcogenides (e.g. $\mathrm{ZnS}$ and $\mathrm{ZnSe}$ ) are sparingly soluble in most solvents, even in hydrazine, two categories of CZTSSe precursor solutions have been previously reported in the literature to fabricate thin-film solar cells: 1) Hydrazine slurries containing in-situ formed $\mathrm{ZnX}$ $\left(\mathrm{N}_{2} \mathrm{H}_{4}\right)(\mathrm{X}=\mathrm{S}, \mathrm{Se})$ particles of a few hundred of nanometers; ${ }^{23,29}$ 2) Molecular precursors composed of dissolved metal salts or metal oxides. ${ }^{30,31}$ In the former case, the compositional fluctuation within the precursor films is significant due to the presence of those particles, while the latter one introduces possible contamination from other elements like oxygen, chlorine, iodine, etc. The complete dissolution of $\mathrm{Zn}$ metal in this primary amine-dithiol solvent system ensures intermixing of precursors on a molecular level and compositional uniformity of deposited CZTSSe thin films. The practicality of this direct solution route is illustrated by depositing CZTSSe 
thin films from metal-metal chalcogenide and metal-chalcogen molecular precursors that give solar cell efficiencies of $6.84 \%$ and $7.02 \%$, respectively, in this preliminary work. Besides the quaternary thin films, binary thin films like ZnS, CuS, and SnS, and ternary thin films of CTSSe were successfully deposited from pure metal, metal chalcogenide, or metal-metal chalcogenide precursor solutions, highlighting the potential of this solution route.

Precursor solutions of pure metals (e.g. $\mathrm{Cu}, \mathrm{Zn}, \mathrm{Sn}$, and In) or binary metal chalcogenides (e.g. $\mathrm{Cu}_{2} \mathrm{~S}, \mathrm{Cu}_{2} \mathrm{Se}$, CuS, CuSe, $\mathrm{SnS}, \mathrm{SnSe}, \mathrm{In}_{2} \mathrm{~S}_{3}, \ln _{2} \mathrm{Se}_{3}, \mathrm{Ag}_{2} \mathrm{~S}$, and $\mathrm{Ag}_{2} \mathrm{Se}$ ) were readily prepared by dissolving bulk powders in solvent mixtures of primary amine (e.g. butylamine (BA), hexylamine (HA), etc.) and 1,2ethanedithiol (EDT) at ambient conditions (Table S1). Fig. 1a and Fig. S1 shows the solutions prepared after the complete dissolution of above bulk powders in HA-EDT solvent mixtures (vol. ratio 1:1). Note that neither HA/BA nor EDT alone

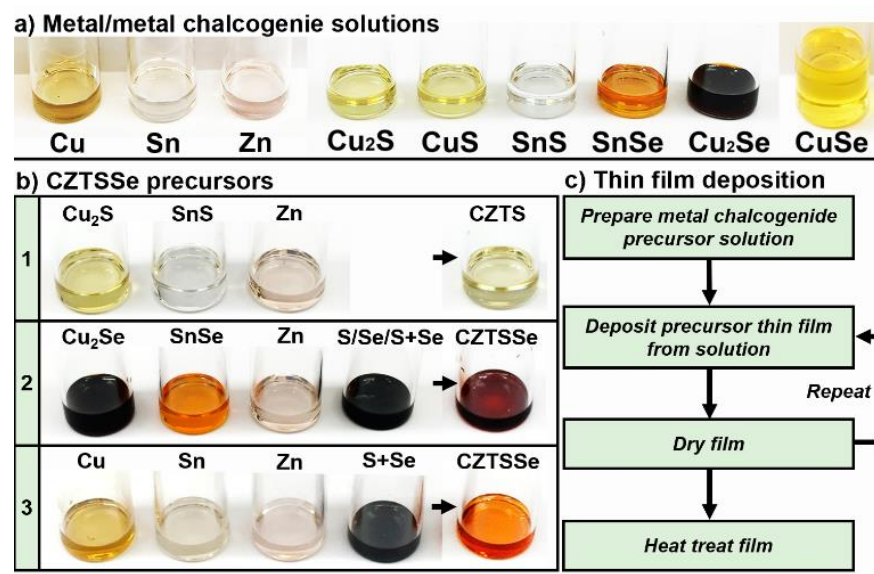

Fig.1 a) Solutions prepared by dissolving $\mathrm{Cu}, \mathrm{Sn}, \mathrm{Zn}, \mathrm{Cu}_{2} \mathrm{~S}, \mathrm{CuS}, \mathrm{SnS}, \mathrm{SnSe}, \mathrm{Cu}_{2} \mathrm{Se}$, and CuSe in solvent mixtures of HA-EDT (vol ratio. 1:1, conc. $0.3 \mathrm{M}$ ) at ambient temperature and pressure. b) Three types of combined precursors and constituent solutions. c) Schematic of general deposition procedures.

dissolves metals or metal chalcogenides. As soon as EDT was added into the mixture of amine and powders at room temperature, the dissolution started immediately, and vice versa. Solubility limits of $\mathrm{Cu}, \mathrm{Zn}, \mathrm{Sn}, \mathrm{Cu}_{2} \mathrm{~S}, \mathrm{Cu}_{2} \mathrm{Se}, \mathrm{SnS}$, and $\mathrm{SnSe}$ in BA-EDT (vol. ratio $1: 1$ ) at $25^{\circ} \mathrm{C}$ are around $0.5,0.78,0.3,0.5$, 0.3 , and $0.3 \mathrm{~mol} / \mathrm{L}$, respectively. All precursor solutions stay optically transparent over months after complete dissolution, indicating the formation of stable organometallic complexes.

To qualitatively understand why bulk metals dissolve in these primary amine-dithiol solvent mixtures, electrolytic conductivity measurements were performed on BA, HA, EDT, BA-EDT solvent mixture, HA-EDT solvent mixture, and solutions with incremental amounts of dissolved $\mathrm{Zn}$ metals at $25^{\circ} \mathrm{C}$ (Table S2). Although BA, HA, and EDT showed zero conductivity, conductivities of $1926.5 \mu \mathrm{S} / \mathrm{cm}$ and $550.2 \mu \mathrm{S} / \mathrm{cm}$ are exhibited by solvent mixtures of BA-EDT (vol. ratio 1:1) and HA-EDT (vol. ratio 1:1), respectively. Furthermore, an inverse relationship between the $\mathrm{Zn}$ concentration and the solution conductivity has been observed. The changes in conductivities indicate charged species are formed as soon as BA/HA and EDT are mixed, and the formation of metal complexes consume some of charged species. It is highly possible that deprotonated thiols and protonated amines are generated in the solvent mixture. The deprontonated thiols and metal ions then formed complexes while the bulk metal was dissolving. The complexes formed are expected to have the similar structure as zinc ethane-1,2-dithiolato complex, [Zn(edt) $\left.{ }_{2}\right]^{2-}$ reported by Rao et $a l^{32}$ The as-dried and as-annealed films of a $\mathrm{Zn}$ solution were characterized using grazing incident $\mathrm{X}$-ray diffraction (GIXRD) (Fig. S2). After annealing at $300^{\circ} \mathrm{C}$, the amorphous precursor film converted to $\mathrm{ZnS}$, which was composed of zincblend ( $\mathrm{F}-43 \mathrm{~m})$ and wurtzite $\mathrm{ZnS}\left(\mathrm{PG}_{3} \mathrm{~m}\right)$ phases. This indicates that EDT acts as a sulfur source for the conversion of a metal into its corresponding metal sulfide.

The re-deposition of metal chalcogenide solutions enables rapid fabrication of a variety of semiconductor thin films. Herein, we show the re-deposition of CuS and SnS solutions as examples. Fig. $2 a$ and $2 b$ show the GIXRD pattern and Raman spectrum of a thin film deposited from CuS solution and subsequently annealed at $300^{\circ} \mathrm{C}$. All the XRD peaks match those in the standard CuS pattern (space group $P \sigma_{3} / \mathrm{mmc}$, JCPDS 06-0464). The Raman shifts exhibit peaks at $266 \mathrm{~cm}^{-1}$ and $474 \mathrm{~cm}^{-1}$ corresponding to covellite CuS reported by Sukarova et al. $^{33}$ In the case of SnS re-deposition, thermogravimetric analysis (TGA) shows an end point of phase transformation at $300^{\circ} \mathrm{C}$ (Fig. S3). The orthorhombic SnS is the only phase formed after annealing at $300^{\circ} \mathrm{C}$, as shown in GIXRD pattern and Raman spectrum (Fig. $2 \mathrm{c}$ and $2 \mathrm{~d}$ ). The Raman peaks at $83,95,163,191,219$, and $288 \mathrm{~cm}^{-1}$ match well with those from a single crystal SnS $(85,95,164,192,218$, and 290 $\left(\mathrm{cm}^{-1}\right) .^{34}$ The above examples illustrated that metal chalcogenides thin films can be recovered from the precursor solutions through efficient deposition technique and wellcontrolled annealing process.
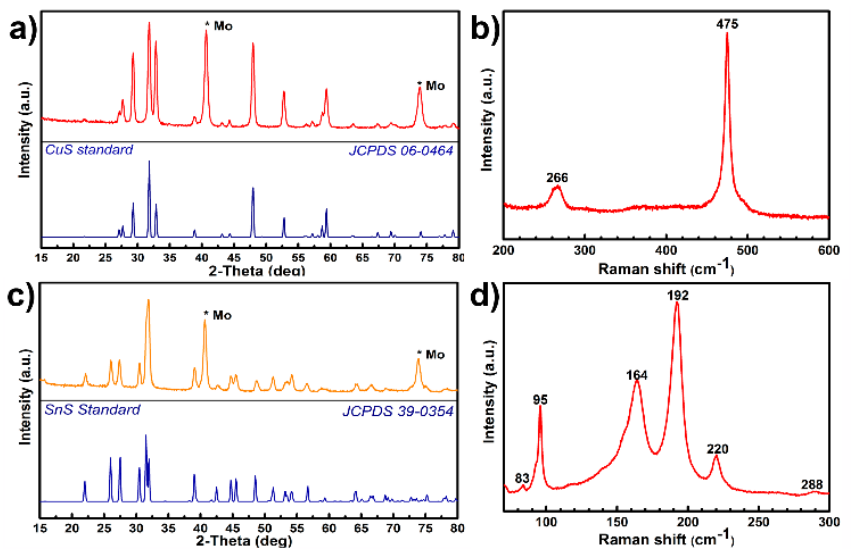

Fig.2 GIXRD patterns and Raman spectra of thin films deposited from CuS and SnS solutions and subsequently annealed at $300^{\circ} \mathrm{C}$. a) and b) CuS, c) and d) SnS.

Owing to the versatility of this primary amine-dithiol solvent mixture in dissolving multiple metal and chalcogen sources at high concentrations, a universal pathway is provided to design molecular precursors for depositing specific metal chalcogenides, especially for ternary and quaternary compounds with tunable bandgaps. To make precursors for ternary $\mathrm{Cu}_{2} \mathrm{Sn}\left(\mathrm{S}_{x} \mathrm{Se}_{1-\mathrm{x}}\right)_{3} \quad(0 \leq x \leq 1)$, solutions of $\mathrm{Cu}_{2} \mathrm{~S} / \mathrm{Cu}_{2} \mathrm{Se}$, 
$\mathrm{SnS} / \mathrm{SnSe}$, and $\mathrm{S} / \mathrm{Se}$ are mixed with proper ratios. The flexibility in adjusting $\mathrm{S}: \mathrm{Se}$ ratios in the precursor solutions allows the fabrication of ternary sulfide, selenide, and sulfoselenide. The GIXRD patterns and film morphology of ternary $\mathrm{Cu}_{2} \mathrm{Sn}\left(\mathrm{S}_{x} \mathrm{Se}_{1-\mathrm{x}}\right)_{3}(0 \leq x \leq 1)$ are shown in Fig. 3 .
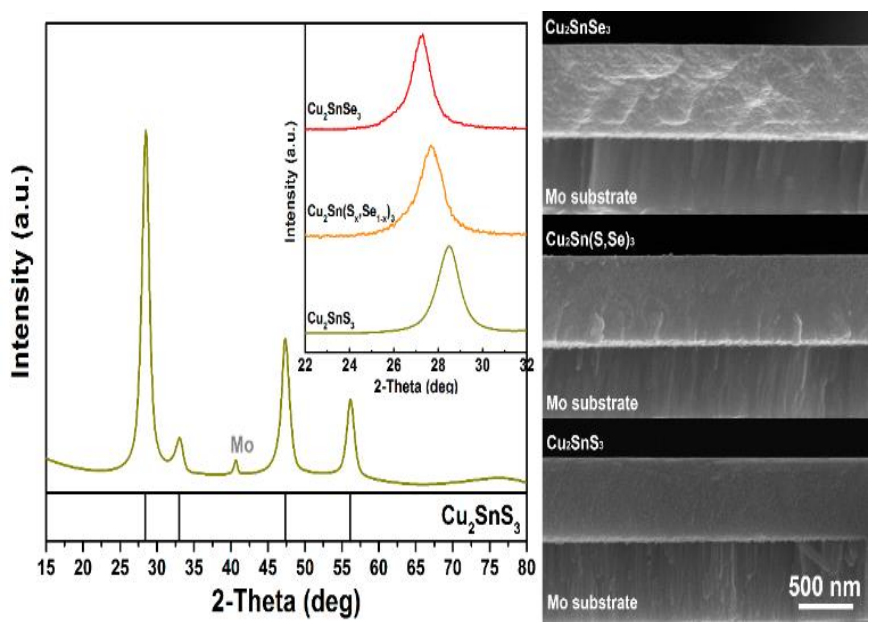

Fig. 3 GIXRD patterns and film morphology of ternary $\mathrm{Cu}_{2} \mathrm{Sn}\left(\mathrm{S}_{x} \mathrm{Se}_{1-x}\right)_{3}(0 \leq x \leq 1)$ thin films processed using mixture solutions of $\mathrm{Cu}_{2} \mathrm{~S} / \mathrm{Cu}_{2} \mathrm{Se}, \mathrm{SnS} / \mathrm{SnSe}$, and $\mathrm{S} / \mathrm{Se}$. The inset shows the shifts in the most intense diffraction with increasing Se concentrations. The compositions of the thin films are estimated using SEM-EDX. The standard pattern of $\mathrm{Cu}_{2} \mathrm{SnS}_{3}$ (PDF 01-070-6338) is labelled at the bottom. Based on Vegard's law, ${ }^{35} \mathrm{x}=0.35$ in the $\mathrm{Cu}_{2} \mathrm{Sn}\left(\mathrm{S}_{\mathrm{x}} \mathrm{Se}_{1-\mathrm{x}}\right)_{3}$ thin film.

To process compositional uniform $\mathrm{Cu}_{2} \mathrm{SnZn}\left(\mathrm{S}_{x} \mathrm{Se}_{1-\mathrm{x}}\right)_{4}$ $(0 \leq x \leq 1)$ thin films, three types of CZTSSe precursor solutions have been explored, that is, Solution 1: CZTS precursor, a mixture of $\mathrm{Cu}_{2} \mathrm{~S}, \mathrm{SnS}$, and $\mathrm{Zn}$ solutions; Solution 2: CZTSSe precursor, a mixture of $\mathrm{Cu}_{2} \mathrm{Se}, \mathrm{SnSe}, \mathrm{Zn}, \mathrm{S}$, and Se solutions; and Solution 3: CZTSSe precursor, a mixture of $\mathrm{Cu}, \mathrm{Sn}, \mathrm{Zn}, \mathrm{S}$, and Se solutions (Fig. 1b). The CZTS and CZTSSe films deposited from Solution 1 and Solution 3 are described in Fig. S4 and Fig. S7. The use of combined solutions in device fabrication will be illustrated in detail using Solution 2:CZTSSe precursor as an example. In Solution 2, [Sn]=0.1 M, [Cu]:[Zn]:[Sn]:[S]:[Se]= 1.45:1.05:1:2:2. The deposition of precursor films includes spin coating, solvent drying/annealing, and a final heat treatment process (Fig. 1c). Typically, eight to ten coatings were performed for solar cell fabrication. A kesterite CZTSSe precursor film was formed after annealing coated Solution 2 at $300^{\circ} \mathrm{C}$, as shown in Fig. $4 \mathrm{a}$ and $4 \mathrm{~b}$. After selenization, Se substituted more $\mathrm{S}$ sites in the crystal lattice, indicated by the intense peak at $197 \mathrm{~cm}^{-1}$ (A1 mode of CZTSe) in contrast to the peak at $329 \mathrm{~cm}^{-1}$ (A1 mode of CZTS) in Raman spectrum (Fig. 4b). No secondary phases were detected by GIXRD or Raman with excitation wavelength of $633 \mathrm{~nm}$. The thin-film solar cells fabricated based on this direct solution route has the highest power conversion efficiency (PCE) of $6.84 \%$ (7.04\%) for a total area of $0.471 \mathrm{~cm}^{2}$ (an active area of $0.457 \mathrm{~cm}^{2}$ ) (Fig. 4c). Other characteristic parameters of this solar cell are: $J_{s c}$ of 35.5 $\mathrm{mA}^{\cdot} \mathrm{cm}^{-2}, \mathrm{~V}_{\text {oc }}$ of $0.36 \mathrm{~V}$, and fill factor (FF) of $53.5 \%$. The bandgap of the absorber layer is estimated to be $1.08 \mathrm{eV}$ based on external quantum efficiency (EQE) measurement (Fig. 4d).
The composition and microstructure of the precursor film and the selenized film were characterized using scanning electron microscopy (SEM) and scanning transmission electron microscopy (STEM) equipped with energy-dispersive X-ray spectroscopy (EDX). Fig. S5 and Table S3 illustrates the SEMEDX results of the precursor film and the selenized film. Highangle annular dark field (HAADF) images in Fig. 5a shows that the precursor film consists of multiple layers which were created by spin coating. The high- and low-contrast regions are attributed to the in-situ formed nanoparticles and low-mass residual solutions. The in-situ formed nanoparticles are less than $5 \mathrm{~nm}$ with a narrow size distribution (Fig. S6). Fig. 5b shows the elemental distributions within a precursor layer and across precursor layers. The compositional fluctuation of this precursor film is much smaller compared to that of the hydrazine-slurry processed precursor film. ${ }^{24} \mathrm{Fig} .5 \mathrm{c}$ and $5 \mathrm{~d}$ are the cross-sectional STEM images and compositional linescan of a processed solar cell. In the absorber layer, a fine-grained layer formed underneath the large-grained layer after selenization (Fig. 5c). The concentrations of $\mathrm{Cu}, \mathrm{Zn}, \mathrm{Sn}, \mathrm{S}$, and Se are uniform in the large-grained layer, while the concentrations of $\mathrm{Cu}$ and $\mathrm{Zn}$ have some fluctuations in the fine-grained layer. The S:Se ratio is believed to have played an important role in changing the grain growth behavior during selenization as reported by colloidal routes studies, ${ }^{5,36}$ leading to the formation of a fine-grained layer in this case.
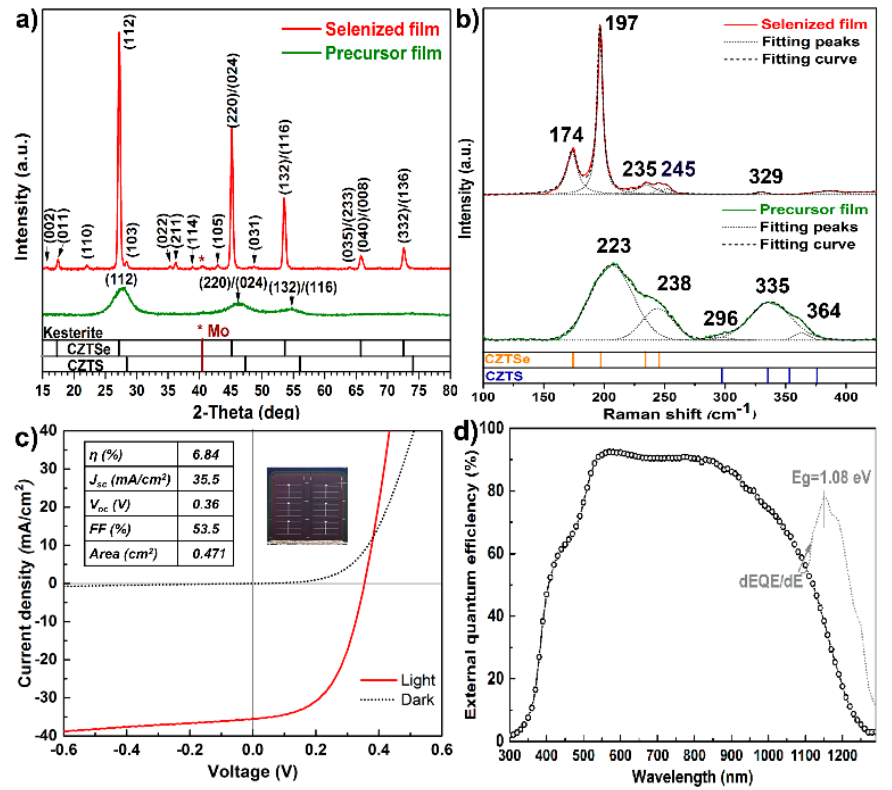

Fig. 4 Results for thin-film solar cells processed from Solution 2: CZTSSe precursor. a) GIXRD patterns and b) Raman spectra of the precursor and the selenized film. c) J-V curves and performance parameters for the best performing cell in the dark and under AM1.5 illumination. The inset is the final device. d) EQE measurement.

Solar cells of CZTSSe were also successfully processed from Solution 3 which is composed of solutions of $\mathrm{Cu}, \mathrm{Zn}, \mathrm{Sn}, \mathrm{S}$, and Se. Our preliminary study shows a PCE of $7.02 \%$ on a total area of $0.4862 \mathrm{~cm}^{2}$ without an anti-reflection coating (Fig. S7). The efficiencies are believed to be improved by increasing the absorber thicknesses.

In conclusion, a primary amine-dithiol solvent system is used for rapid dissolution of bulk metals (e.g. $\mathrm{Cu}, \mathrm{Zn}, \mathrm{Sn}$, and 
In) and metal chalcogenides (e.g. $\mathrm{Cu}_{2} \mathrm{~S}, \mathrm{Cu}_{2} \mathrm{Se}, \mathrm{CuS}$, CuSe, SnS, SnSe, $\ln _{2} \mathrm{~S}_{3}, \ln _{2} \mathrm{Se}_{3}, \mathrm{Ag}_{2} \mathrm{~S}$, and $\mathrm{Ag}_{2} \mathrm{Se}$ ). The extensive applications of solution routes based on this versatile solvent system is demonstrated by film deposition of CuS, SnS, ZnS, CTSSe, CZTS, and CZTSSe. The unique capability to dissolve $\mathrm{Zn}$ powders at room temperature allows the formation of molecular precursors for CZTSSe deposition, and promotes the phase purity and compositional uniformity in the final films. Furthermore, the use of the metal-metal chalcogenide precursor solutions offers flexibility in tailoring the stoichiometry of the resulting films simply by adjusting the types and concentrations of the incorporated component solutions. Preliminary results of the solar cell performances illustrate the potential of this direct solution route for photovoltaic device and other electronic applications. We expect that the efficiencies will improve after further refinement in film compositions and heat treatment conditions.
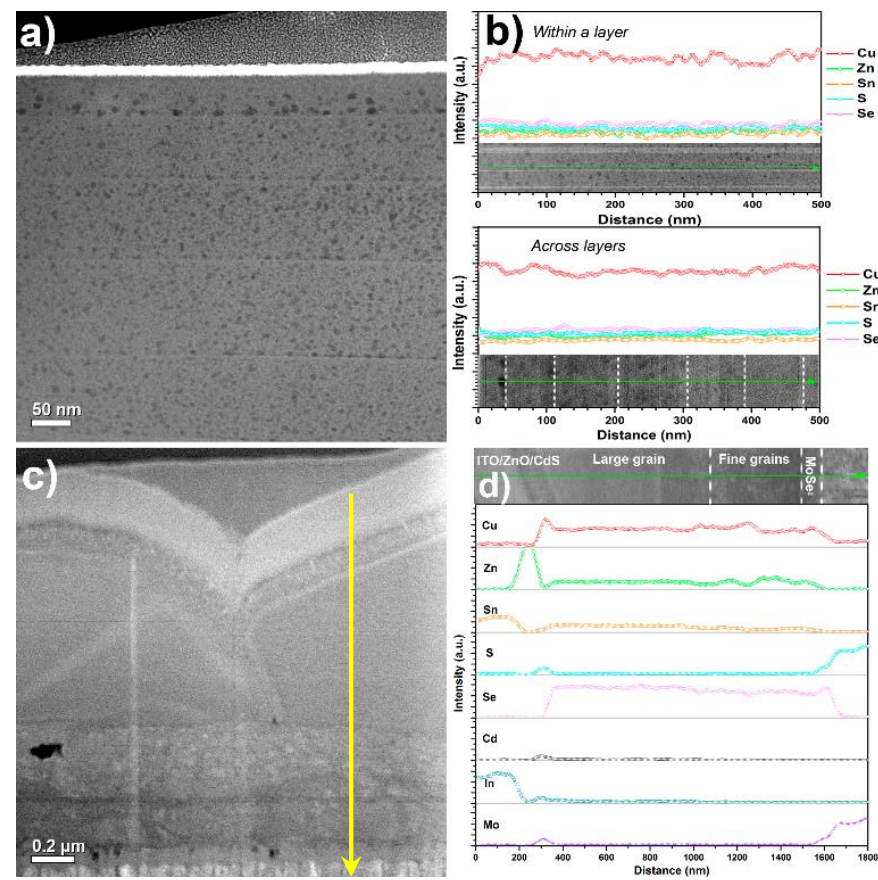

Fig. 5 Results for Solution 2: CZTSSe precursor. a) STEM-HAADF images of CZTSSE precursor film. b) STEM-EDX compositional profiling of $\mathrm{Cu}, \mathrm{Zn}, \mathrm{Sn}, \mathrm{S}$, and Se within a single layer of precursor film and across several precursor films. c) Cross-sectional STEM-HAADF image of a processed solar cell. d) STEM-EDX compositional profiling show the distribution of elements in this device. Note that X-rays of $S K^{\alpha 1}$ and $M_{0} L^{\alpha 1}$ overlap each other, and thus the compositional profiles are the same.

The authors acknowledge C. K. Miskin, R. Boyne, P. Murria, L. Cain and Professor H. Kenttamaa, for assisting in the solution analysis. The authors also want to thank $M$. Koeper for performing quantum efficiency measurement, K. Brew and B. Graeser for preparing Mo-coated soda lime glass. This research was funded by NSF Solar Economy IGERT program (0903670-DGE). This research used resources of the Center for Functional Nanomaterials, which is a U.S. DOE Office of Science Facility, at Brookhaven National Laboratory under Contract No. DE-SC0012704.

\section{References}

1. J. A. Bragagnolo, A. M. Barnett, J. E. Phillips, R. B. Hall, A. Rothwarf and J. D. Meakin, Electron Devices, IEEE Transactions on, 1980, 27, 645.

2. S. C. Riha, B. A. Parkinson and A. L. Prieto, Journal of the American Chemical Society, 2009, 131, 12054.

3. Q. Guo, G. M. Ford, W.-C. Yang, B. C. Walker, E. A. Stach, H. W. Hillhouse and R. Agrawal, J Am Chem Soc, 2010, 132, 17384.

4. S. C. Riha, B. A. Parkinson and A. L. Prieto, Journal of the American Chemical Society, 2011, 133, 15272.

5. C. K. Miskin, W.-C. Yang, C. J. Hages, N. J. Carter, C. S. Joglekar, E. A. Stach and R. Agrawal, Progress in Photovoltaics: Research and Applications, 2015, 23, 654

6. H. Okimura, T. Matsumae and R. Makabe, Thin Solid Films, 1980, 71, 53.

7. K. T. Ramakrishna Reddy, N. Koteswara Reddy and R. W. Miles, Solar Energy Materials and Solar Cells, 2006, 90, 3041.

8. P. Sinsermsuksakul, K. Hartman, S. Bok Kim, J. Heo, L. Sun, H. Hejin Park, R. Chakraborty, T. Buonassisi and R. G. Gordon, Appl Phys Lett, 2013, 102 053901.

9. C. Steinhagen, M. G. Panthani, V. Akhavan, B. Goodfellow, B. Koo and B. A. Korgel, Journal of the American Chemical Society, 2009, 131, 12554.

10. J. Tang, Z. Huo, S. Brittman, H. Gao and P. Yang, Nat Nano, 2011, 6, 568.

11. J. Lim, M. Park, W. K. Bae, D. Lee, S. Lee, C. Lee and K. Char, Acs Nano, 2013, 7, 9019

12. H. Shen, X. Bai, A. Wang, H. Wang, L. Qian, Y. Yang, A. Titov, J. Hyvonen, Y. Zheng and L. S. Li, Adv Funct Mater, 2014, 24, 2367.

13. M. Catti, Y. Noel and R. Dovesi, J Phys Chem Solids, 2003, 64, 2183-2190.

14. M.-Y. Lu, J. Song, M.-P. Lu, C.-Y. Lee, L.-J. Chen and Z. L. Wang, Acs Nano, 2009, 3, 357

15. H. Liu, X. Shi, F. Xu, L. Zhang, W. Zhang, L. Chen, Q. Li, C. Uher, T. Day and G. J. Snyder, Nat Mater, 2012, 11, 422.

16. S. Sassi, C. Candolfi, J.-B. Vaney, V. Ohorodniichuk, P. Masschelein, A. Dauscher and B. Lenoir, Appl Phys Lett, 2014, 104, 212105.

17. L.-D. Zhao, S.-H. Lo, Y. Zhang, H. Sun, G. Tan, C. Uher, C. Wolverton, V. P. Dravid and M. G. Kanatzidis, Nature, 2014, 508, 373.

18. D. B. Mitzi, J Mater Chem, 2004, 14, 2355.

19. D. B. Mitzi, Adv Mater, 2009, 21, 3141.

20. D. B. Mitzi, T. K. Todorov, O. Gunawan, Y. Min, C. Qing, L. Wei, K. B. Reuter, M. Kuwahara, K. Misumi, A. J. Kellock, S. J. Chey, T. G. de Monsabert, A. Prabhakar, V. Deline and K. E. Fogel, EEE Photovoltaic Specialists Conference, 2010, 35, 00640.

21. D. B. Mitzi, M. Yuan, W. Liu, A. J. Kellock, S. J. Chey, V. Deline and A. G. Schrott, Adv Mater, 2008, 20, 3657.

22. T. K. Todorov, O. Gunawan, T. Gokmen and D. B. Mitzi, Prog Photovoltaics, 2013, 21, 82.

23. T. K. Todorov, K. B. Reuter and D. B. Mitzi, Adv Mater, 2010, 22, E156.

24. T. K. Todorov, J. Tang, S. Bag, O. Gunawan, T. Gokmen, Y. Zhu and D. B. Mitzi, Adv Energy Mater, 2013, 3, 34.

25. P. D. Antunez, D. A. Torelli, F. Yang, F. A. Rabuffetti, N. S. Lewis and R. L. Brutchey, Chem Mater, 2014, 26, 5444.

26. D. H. Webber and R. L. Brutchey, Journal of the American Chemical Society, 2013, 135, 15722.

27. D. H. Webber, J. J. Buckley, P. D. Antunez and R. L. Brutchey, Chemical Science, 2014, 5, 2498

29. Z. Lin, Q. He, A. Yin, Y. Xu, C. Wang, M. Ding, H.-C. Cheng, B. Papandrea, Y. Huang and X. Duan, Acs Nano, 2015, 9, 4398.

28. T. Todorov, H. Sugimoto, O. Gunawan, T. Gokmen and D. B. Mitzi, leee J Photovolt, 2014, 4, 483.

30. Q. Tian, G. Wang, W. Zhao, Y. Chen, Y. Yang, L. Huang and D. Pan, Chem Mater, 2014, 26, 3098.

31. R. Zhang, S. M. Szczepaniak, N. J. Carter, C. A. Handwerker and R. Agrawal, Chem Mater, 2015, 27, 2114-2120.

32. C. P. Rao, J. Dorfman and R. Holm, Inorg Chem, 1986, 25, 428.

33. B. Minceva-Sukarova, M. Najdoski, I. Grozdanov and C. Chunnilall, Journal of molecular structure, 1997, 410, 267.

34. H. Chandrasekhar, R. Humphreys, U. Zwick and M. Cardona, Phys Rev B, 1977, 15, 2177.

35. A. R. Denton and N. W. Ashcroft, Physical Review A, 1991, 43, 3161.

36. B. C. Walker, B. G. Negash, S. M. Szczepaniak, K. W. Brew and R. Agrawal, Photovoltaic Specialists Conference (PVSC), 2013, IEEE 39, 2548. 